\title{
The invasive Yellow Crazy Ant and the decline of forest ant diversity in Indonesian cacao agroforests
}

\author{
Merijn M. Bos · Jason M. Tylianakis • \\ Ingolf Steffan-Dewenter $\cdot$ Teja Tscharntke
}

Received: 19 July 2007 / Accepted: 2 January 2008/Published online: 12 January 2008

(C) Springer Science+Business Media B.V. 2008

\begin{abstract}
Throughout the tropics, agroforests are often the only remaining habitat with a considerable tree cover. Agroforestry systems can support high numbers of species and are therefore frequently heralded as the future for tropical biodiversity conservation. However, anthropogenic habitat modification can facilitate species invasions that may suppress native fauna. We compared the ant fauna of lower canopy trees in natural rainforest sites with that of cacao trees in agroforests in Central Sulawesi, Indonesia in order to assess the effects of agroforestry on occurrence of the Yellow Crazy Ant Anoplolepis gracilipes, a common invasive species in the area, and its effects on overall ant richness. The agroforests differed in the type of shadetree composition, tree density, canopy cover, and distance to the village. On average, $43 \%$ of the species
\end{abstract}

M. M. Bos ( $\square)$

Department of Entomology, State Museum of Natural

History, Rosenstein 1, 70191 Stuttgart, Germany

e-mail: boommarter@hotmail.com

M. M. Bos · J. M. Tylianakis - I. Steffan-Dewenter ·

T. Tscharntke

Department of Agroeocology, University of Göttingen,

Waldweg 26, 37077 Gottingen, Germany

J. M. Tylianakis

School of Biological Sciences, University of Canterbury, Private bag 4800, 8020 Christchurch, New Zealand

I. Steffan-Dewenter

Department of Animal Ecology I, University of Bayreuth, 95440 Bayreuth, Germany in agroforests also occurred in the lower canopy of nearby primary forest and the number of forest ant species that occurred on cacao trees was not related to agroforestry characteristics. However, A. gracilipes was the most common non-forest ant species, and forest ant richness decreased significantly with the presence of this species. Our results indicate that agroforestry may have promoted the occurrence of A. gracilipes, possibly because tree management in agroforests negatively affects ant species that depend on trees for nesting and foraging, whereas A. gracilipes is a generalist when it comes to nesting sites and food preference. Thus, agroforestry management that includes the thinning of tree stands can facilitate ant invasions, thereby threatening the potential of cultivated land for the conservation of tropical ant diversity.

Keywords Agriculture - Biological invasion · Competition - Formicidae - Managed land . Microclimate - Interspecific interactions · Land use intensity

\section{Introduction}

Global-scale conversion of natural ecosystems to agriculture is recognized as the major cause of biodiversity loss, and threatens ecosystem functioning, sustainability and economic security (Hoekstra et al. 2005). Tropical rainforests are one of the most species rich and functionally important terrestrial 
ecosystems on earth (Myers et al. 2000), of which an estimated $32 \%$ has been converted to humandominated systems in the past 50 years and a further loss of 10-15\% has been projected by 2050 (Millenium Ecosystem Assessment 2005). The hot spot of tropical rainforest conversion is Southeast Asia, with average annual deforestation rates of 2.5 million hectares (Achard et al. 2002). With the continuing loss of tropical forests, cultivated areas are gaining interest for their potential value for conserving tropical biodiversity in the frontier between human cultivation and pristine ecosystems (Rice and Greenberg 2000; Bawa et al. 2004; Tscharntke et al. 2005).

Conservation research has begun to examine the contribution of cultivated forests (agroforests) to local and regional biodiversity, partly due to their low management intensity, and the superficial resemblance of these systems to natural forest (Rice and Greenberg 2000; Bawa et al. 2004; McNeely 2004; Schroth et al. 2004). Agroforests can indeed support high levels of species richness, even resembling that of undisturbed tropical forests (Room 1971; Majer et al. 1994; Perfecto et al. 1997; Schulze et al. 2004; Tylianakis et al. 2006). However, the species richness supported depends on the complexity of the agroforest habitat (Armbrecht et al. 2004; SteffanDewenter et al. 2007), and recent intensification of existing tropical agroforests has caused rapid declines in associated biodiversity (Perfecto et al. 1997; Schulze et al. 2004; Bos et al. 2007a).

Despite this wealth of recent studies, little is known about the mechanisms that drive detected trends in biodiversity and the extent to which native forest fauna and widespread, exotic species are represented in the biodiversity of agroforests. In the case of ants, invasions by non-native species can seriously disrupt indigenous ant assemblages and even threaten native species (Holway et al. 2002a; Hill et al. 2003; O'Dowd et al. 2003; Sanders et al. 2003). Generally, such invasions may be context dependent in that anthropogenic disruption of ecosystems negatively affects native species assemblages and thus pave the way for species invasions (Elton 1958; Didham et al. 2007). Competitive interactions between ant species may change as a result of abiotic (Holway et al. 2002b; Gibb and Hochuli 2003) and structural (Armbrecht et al. 2004) environmental changes, which have also been suggested to drive ant invasions (Holway et al. 2002a).
Here we study the ant fauna of lower canopy trees in natural forests and cacao trees in agroforests in Central Sulawesi, Indonesia. In the study area, the Yellow Crazy Ant Anoplolepis gracilipes (Smith 1857) (Hymenoptera: Formicidae) is a common ant species (Bos et al. 2007a). This species is among the most aggressive invasive ants in the world and is non-native in most of its current Indo-Pacific distribution (Holway et al. 2002a; Wetterer 2005). A. gracilipes has been implicated in ecological meltdowns (Hill et al. 2003; O'Dowd et al. 2003) because of profound effects of the ant on local fauna, as well as indirect effects on undergrowth and endemic bird populations. Such invasions are therefore posed as a basic mechanism behind worldwide declines in biodiversity (Vitousek et al. 1996). Our main objectives were (1) to quantify the proportion of forest and non-forest ant fauna on cacao trees in agroforests and (2) to distinguish between the effects of forest conversion to agroforests and the occurrence of A. gracilipes on ant diversity in a tropical biodiversity hotspot.

\section{Methods}

Study site selection and characterisation

The study took place in and around the village of Toro in the Kulawi Valley, Central Sulawesi, Indonesia (Fig. 1). The village is at the western border of the 231,000 ha Lore Lindu National Park, about $100 \mathrm{~km}$ south of Palu, the capital city of Central Sulawesi. The region has an annual average $( \pm \mathrm{SE})$ temperature of $24.0( \pm 0.16){ }^{\circ} \mathrm{C}$ and a mean monthly rainfall of $143.7( \pm 22.74) \mathrm{mm}$. There is no clear seasonality. The natural vegetation of the National Park around the village is submontane rainforest, whereas all forest types in the village area were agroforests.

We defined a priori three types of agroforests, which differed in shade tree composition (number of native tree species per 0.25 ha), but were comparable in terms of percent canopy cover and stem density (Table 1). Four sites of each type were selected (Fig. 1b). The distance between agroforests and the village (measured as shortest distance in meters to the nearest village road) was always less than between the village and the natural forest sites (Table 1). The three agroforest types were: 
Fig. 1 The Indonesian island of Sulawesi (a) with the three largest cities and the Lore Lindu National Park in Central Sulawesi with the study area indicated with *, and (b) a satellite image of the study area showing the distribution of study sites around the village Toro in Central Sulawesi. A1-4 are natural forest sites within the Lore Lindu National Park, B1-4 are agroforests shaded by forest remnants, C1-4 are agroforests shaded by diverse stands of planted trees and D1-4 agroforests shaded by one or two species of planted shade trees. Study sites are indicated with small circles where Anoplolepis gracilipes was absent and with large circles where the invasive ant was present. (Image source: QUICKBIRD UTM51SWGS84. Processed and provided by André Twele, Göttingen University, Germany)

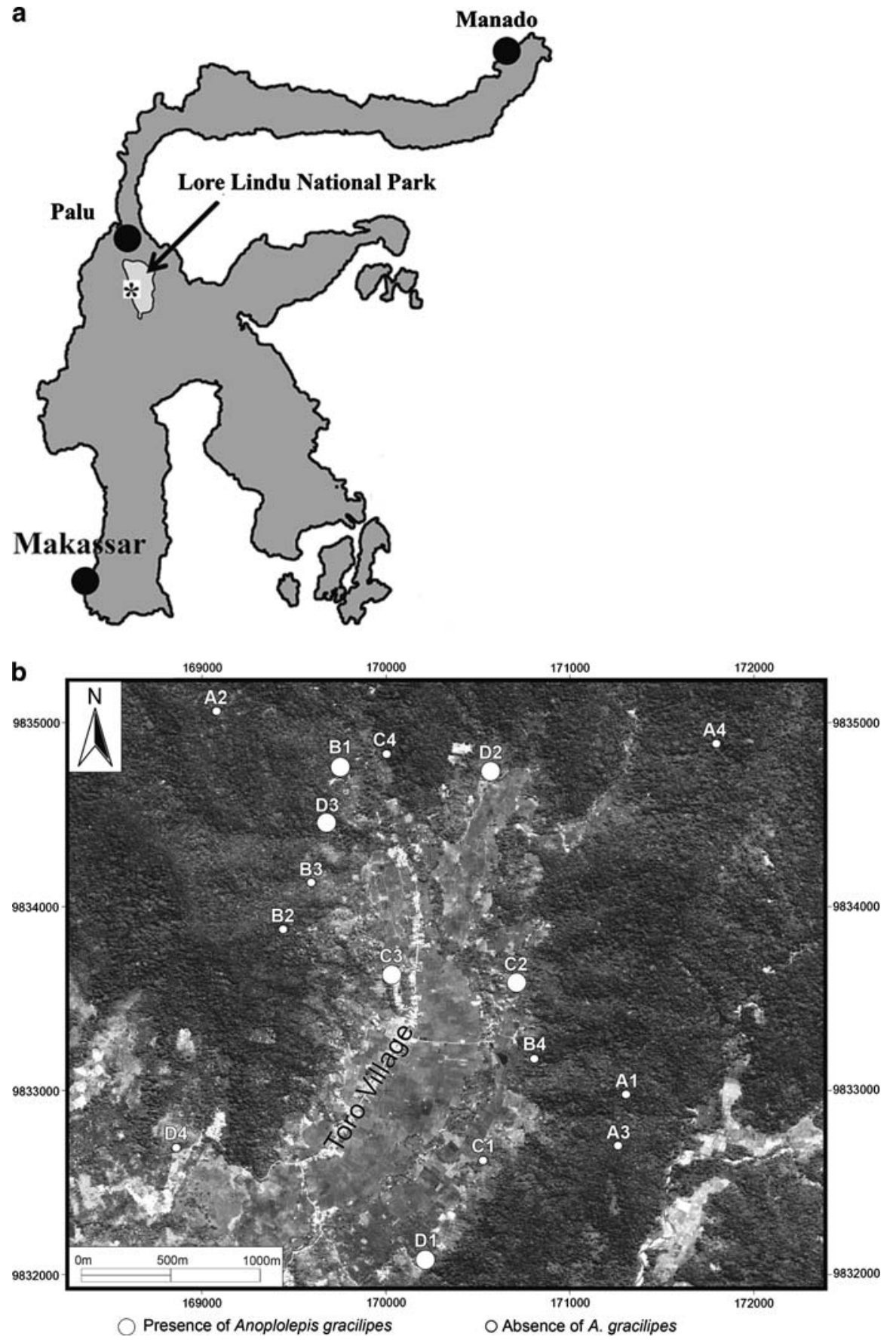

i) Cacao agroforests with diverse, natural shade tree stands that were retained from previously undisturbed forest when it was thinned and underplanted with cacao. Cacao agroforestry was the first form of cultivation in these sites. These agroforests still have high numbers of native shade tree species, and even some endemic species. Canopy cover is slightly higher than in the other two types of agroforests (Table 1).

ii) Cacao agroforests with planted shade tree stands dominated by various cultivated species. These sites have a longer history of cultivation (e.g., as 
Table 1 Characteristics of the selected habitat types: Natural forest (NF), cacao under diverse natural shade (DNS), cacao under diverse planted shade (DPS) and cacao under simple planted shade (SPS) in Central Sulawesi, Indonesia. Values are averaged per habitat type (means $\pm \mathrm{SE}$ )

\begin{tabular}{|c|c|c|c|c|}
\hline Site characteristic & $\mathrm{NF}(\mathrm{n}=4)$ & DNS $(n=4)$ & DPS $(n=4)$ & SPS $(n=4)$ \\
\hline Tree species ${ }^{1}$ & $55.8 \pm 2.75^{\mathrm{a}}$ & $20.8 \pm 3.90^{\mathrm{b}}$ & $19.0 \pm 3.75^{\mathrm{b}}$ & $9.0 \pm 2.25^{\mathrm{b}}$ \\
\hline Native tree species ${ }^{1}$ & $55.8 \pm 2.75^{\mathrm{a}}$ & $18.5 \pm 3.95^{\mathrm{b}}$ & $10.3 \pm 4.40^{\mathrm{bc}}$ & $5.5 \pm 1.85^{\mathrm{c}}$ \\
\hline Endemic tree species ${ }^{1}$ & $8.0 \pm 0.40^{\mathrm{a}}$ & $2.3 \pm 1.30^{\mathrm{b}}$ & $0.8 \pm 0.75^{\mathrm{b}}$ & $0^{\mathrm{b}}$ \\
\hline Planted tree species ${ }^{1}$ & $0^{\mathrm{a}}$ & $2.3 \pm 0.50^{\mathrm{b}}$ & $8.8 \pm 0.65^{\mathrm{c}}$ & $3.5 \pm 0.50^{\mathrm{b}}$ \\
\hline Tree density $^{1}$ & $139.5 \pm 11.24^{\mathrm{a}}$ & $78.8 \pm 10.38^{\mathrm{ab}}$ & $70.0 \pm 11.03^{\mathrm{b}}$ & $84.5 \pm 25.52^{\mathrm{ab}}$ \\
\hline Canopy cover $(\%)$ & $95.6 \pm 0.78^{\mathrm{a}}$ & $72.5 \pm 4.47^{\mathrm{ab}}$ & $61.4 \pm 6.34^{\mathrm{b}}$ & $58.1 \pm 8.40^{\mathrm{b}}$ \\
\hline Distance to the village (meters) & $1618.6 \pm 194.04^{\mathrm{a}}$ & $696.0 \pm 101.23^{\mathrm{b}}$ & $600.3 \pm 153.95^{\mathrm{b}}$ & $425 \pm 166.49^{\mathrm{b}}$ \\
\hline \multicolumn{5}{|l|}{ Ant species richness } \\
\hline Observed & $15.8 \pm 3.09$ & $16.0 \pm 1.58$ & $11.5 \pm 2.10$ & $14.0 \pm 2.48$ \\
\hline Estimated $^{2}$ & $24.1 \pm 5.04$ & $26.0 \pm 2.61$ & $18.6 \pm 3.48$ & $21.7 \pm 3.48$ \\
\hline
\end{tabular}

Values indicated with different letters $(a, b, c)$ within a row differ significantly based on one-way ANOVA's and Tukey HSD posthoc tests. Shade canopy cover is adapted from Bos et al. (2007b) and values for tree species richness and tree density from Gradstein et al. (2007)

1 Values are per 0.25 ha

2 First order Jackknife estimator

coffee agroforests) and trees from the previous forest cover were all replaced by various planted fruit and timber trees, that additionally provide the owners with non-market products. Among these trees were some native (occasionally endemic) species. Tree density was slightly lower than in the other two types of agroforests (Table 1).

iii) Cacao agroforests with a low diversity of planted shade trees of the non-indigenous leguminous tree species Gliricidia sepium and Erythrina subumbrans, which are planted to promote nitrogen availability for the cacao trees. These sites have a longer history of cultivation (e.g., as coffee plantations or annual crops) and management was aimed at maximum cacao productivity. Some native timber or fruit tree species were grown, none of which were endemic.

Cacao production in the region increased strongly in the 1990s (Potter 2001). At the time of this study, agroforestry was generally non-intensive, with little use of fertilizers and pesticides on the selected sites. Farmers regularly pruned trees and removed herb and litter layers (2-3 times per year). The selected cacao agroforests form part of a continuous band of agroforests along the forest margin (Fig. 1b). Boundaries between agroforests were arbitrarily based on ownership. Therefore, we marked core areas of $30 \times 50 \mathrm{~m}$ in the middle of each site for sampling.
Land-use and types of shade tree stands did not change within these areas.

Four forest sites were selected close to the village, but well within the national park (Fig. 1b), and were representative of the submontane forest in the area. In these forest sites minor rattan extraction occurred. The sites had over 50 tree species per 0.25 ha and a basal area $\left(\mathrm{m}^{2} / \mathrm{ha}\right)$ that was high compared to other primary forests in Southeast Asia (Gradstein et al. 2007).

The different habitat types were geographically interspersed and sites were at least $300 \mathrm{~m}$ away from one another (Fig. 1b). The maximum distance between two study sites was about $5 \mathrm{~km}$. All sites were between 850 and $1,100 \mathrm{~m}$ above sea level.

\section{Collecting ants from small lower canopy trees}

The ant fauna was captured from six lower canopy trees per site (96 trees in total). In the agroforests, all trees were cacao trees because no other tree species made up the lower canopy. In each of the natural forest sites 6 lower canopy trees were selected that had similar canopy sizes compared to the 72 selected cacao trees in the agroforests. The 24 trees at the forest sites were identified by R. Pitopang of the Herbarium Celebense, Palu, Indonesia and belonged to 21 species of 15 families (see Appendix 1). On one occasion only were two trees in one forest site of the 
same species. By sampling such a heterogeneous set of tree species in the forests sites, we ensured the broadest possible characterization of ant fauna that can be found in natural lower forest canopy.

Lower canopy-dwelling ant fauna was sampled using canopy knockdown fogging which is an effective and widely used technique for collecting arthropods from tree crowns (e.g., Perfecto et al. 1997). With a SwingFog TF35 fogging machine, a fog of $1 \%$ pyrethroid insecticide $\left(\right.$ Permethrin ${ }^{\odot}$ ) was blown horizontally into the subject canopy to avoid affecting higher, shading canopy layers. All sampling was carried out on one randomly selected site per day between 8.00 and 9.00 am from April to May 2005 . Killed ants were collected from a $4 \mathrm{~m}^{2}$ sheet of white canvas placed directly under each tree. With this standardized collection method care was taken to reduce bias due to contamination of our samples with specimens from outside the subject canopy.

\section{Identifications}

The study of biodiversity in the tropics is a challenge due to extremely high species richness and the fact that the majority of that richness to date remains undescribed by taxonomy (Basset 2001). With the help of ant experts Akhmad Rizali (Bogor, Indonesia) and Rudy Kohout (Queensland, Australia), literature (Bolton 1994) and reliable digital resources (e.g., http: //www.antweb.org and http://www.antbase.de) the ants were identified to genus and further sorted to morphospecies (hereafter: species). All species were photographed and presented on the internet (http:// www.ant-diversity.com).

Because of the general lack of distributional and ecological information at the species level, ant species were categorized as forest species when they occurred in at least one forest site and the remaining species found only in agroforests were termed non-forest species. This arbitrary distinction can result in an overestimate that could decrease if more forest sites are sampled. Therefore, we only compare amounts of forest and non-forest species on the tree or site level.

\section{Statistical analyses}

From the observed ant species richness per site, we calculated first order Jackknife estimators for species richness (Schulze et al. 2004). Per site observed and estimated species richness were compared between habitat types using a one-way ANOVA. The variation in ant species richness per tree was compared in forests and agroforests using a nested ANOVA with habitat type as a fixed factor and trees nested within sites. As the focus of our investigation was on the effects of agroforestry simplification and because the diversity of tree species in the forest made comparison with agroforests difficult, all further analyses were conducted solely on agroforests $\left(\mathrm{n}_{\text {sites }}=12\right.$ and $\left.\mathrm{n}_{\text {trees }}=72\right)$.

As canopy cover and tree density were available per site (Table 1) and not significantly intercorrelated $\left(\mathrm{R}_{\text {Spearman }}=0.22, P>0.05\right)$, effects on species richness were tested at the site level in a general linear model with type I variance decomposition and habitat type entered first as fixed factor, followed by the two continuous predictor variables (canopy cover and tree density). Responses of cacao-dwelling ant species richness to the presence of Anoplolepis gracilipes on cacao trees were evaluated for total ant richness, richness of forest ants, and richness of non-forest ants using general linear models (GLMs) with habitat type as a fixed variable and trees nested within sites, followed by presence/absence of the invasive species. Data were square root transformed where necessary to achieve normal distribution of model residuals. To predict presence of $A$. gracilipes with changing canopy cover and tree density, logistic regressions were carried out on presence-absence data at the site level. In addition, logistic regression was carried out to test for the effect of distance to the village on the presence of A. gracilipes in the agroforests.

First order Jackknife estimators for species richness were calculated using EstimateS (Colwell 2004). All other analyses were done using Statistica 7.0 (StatSoft inc. 1984-2004). Arithmetic means are given \pm 1 standard error.

\section{Results}

A total of 13,835 ants were collected from 24 small lower canopy trees in four forest sites and from 72 cacao trees in 12 agroforests (shaded by three types of tree stands: diverse natural shade, diverse planted shade and simple planted shade). The ants were identified to 7 subfamilies and 16 genera, which were sorted to 84 species (Appendix 2). Forty species 


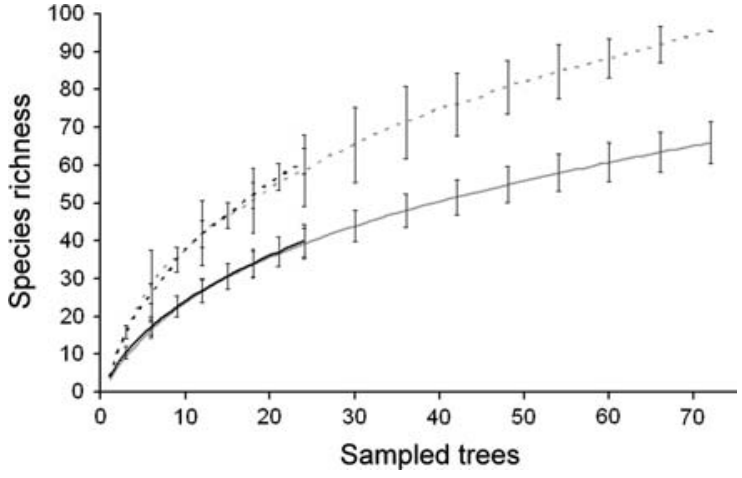

Fig. 2 Species accumulation curves of the observed (continuous lines) and first order Jackknife estimated (dotted lines) species richness in natural forest sites (24 trees, black lines) and cacao agroforests (72 trees, grey lines) in Central Sulawesi, Indonesia. Bars indicate standard deviations

were recorded in the natural forest sites and 66 species in the agroforests (Fig. 2). In the natural forests, observed species richness was $69 \%$ of the estimated species richness and in the agroforests this percentage reached $65 \%$. The species accumulation curves were similar in the natural forests and agroforests (Fig. 2).

The 40 species from the natural forest were assigned as forest species, and the remaining 44 species were assigned as non-forest species (i.e., found in the agroforests only). Twenty-two forest species (55\%) were collected from cacao trees in the agroforests as well. Observed and estimated species richness per site did not differ between the forest and agroforest sites (ANOVA observed species richness: $\mathrm{F}_{(3,12)}=0.76$, $P=0.54$, and estimated species richness: $\mathrm{F}_{(3,12)}=$ $0.72, P=0.56$, Table 1$)$. Average species richness on the lower canopy forest trees was $4.16 \pm 0.38$ and on cacao trees $3.77 \pm 0.20\left(\mathrm{GLM} \mathrm{F}_{(3,12)}=0.23, P=\right.$ 0.87 , Fig. 3). The number of forest species dropped significantly on cacao trees, but did not differ between agroforestry types $\left(\operatorname{GLMF}_{(3,12)}=16.96, P<0.05\right.$ and Tukey's HSD post hoc test, Fig. 3), indicating a large turnover in species from forest to agroforest. Cacao trees supported on average $1.58 \pm 0.13$ forest species.

Anoplolepis gracilipes response to agroforest modification

In total 2,287 individuals of the Yellow Crazy Ant Anoplolepis gracilipes were collected from 14 trees, which made this species the most abundant non-forest

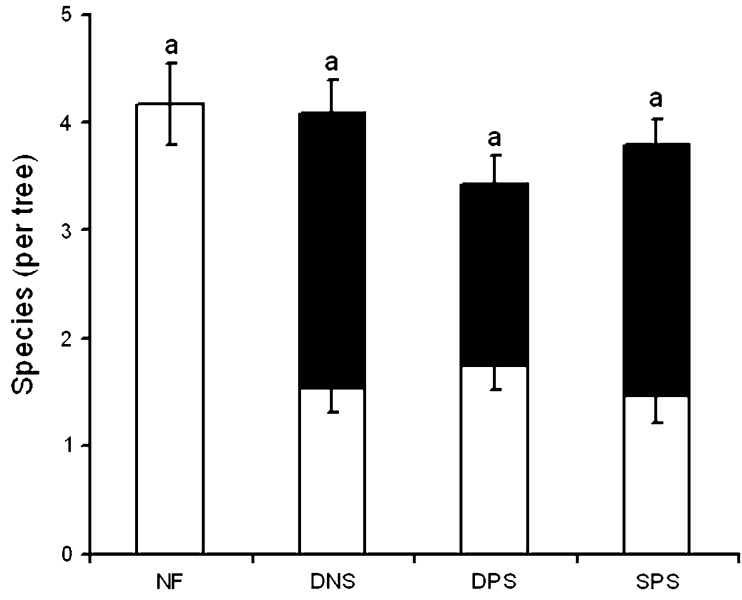

Fig. 3 The effect of forest conversion on the overall and forest ant species richness per tree $( \pm$ SE) given per habitat type in Central Sulawesi, Indonesia. Habitat types from left to right: natural forest, cacao under diverse natural shade, cacao under planted diverse shade and cacao under simple, planted shade. Forest species are in black. Letters show significant differences $(P<0.05)$ according to Tukey's HSD post hoc test after the General Linear Model

species (Appendix 1). A. gracilipes was found only once on cacao under complex, natural shade and not at all on the lower canopy trees in the nearby forest sites. In one agroforest with simple planted shade, the ant occurred on all investigated trees.

Because the abundance of $A$. gracilipes was not normally distributed before or after square root transformations, the following analyses were carried out on the basis of presence-absence on cacao trees. The number of cacao trees on which the ant occurred did not differ significantly between the three agroforestry types $\left(\mathrm{F}_{(2,9)}=2.0, P=0.19\right)$. Furthermore, the probability of presence in sites was weakly related to tree density, with the highest probability of occurrence in sites with lowest tree density (Logistic regression $\chi^{2}=3.86, P=0.07$, Fig. 4), but was not related to canopy cover (Logistic regression $\left.\chi^{2}=0.002, P=0.96\right)$ nor to distance to the village (Logistic regression $\chi^{2}=0.33, P=0.56$ ).

Species richness on cacao trees in relation to agroforest modification and presence of Anoplolepis gracilipes

Richness of forest and non-forest ant species in agroforests were not affected by the type of agroforest 


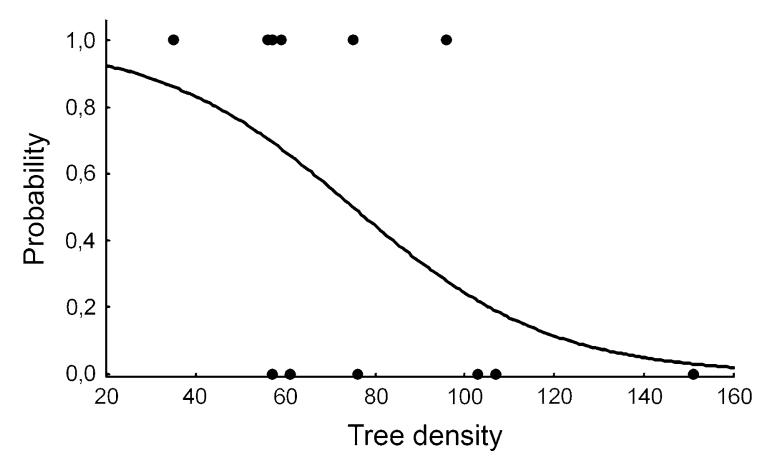

Fig. 4 The probability of presence of the invasive Crazy Ant Anoplolepis gracilipes on cacao trees (y-axis) with increasing tree density (x-axis) in Central Sulawesi, Indonesia as calculated by logistic regression

(Fig. 2) or by changes in canopy cover (GLM: $\mathrm{F}_{(1,7)}=1.16, P=0.31$ and $\mathrm{F}_{(1,7)}=0.02, P=0.87$ respectively) and tree density $\left(\mathrm{GLM}: \mathrm{F}_{(1,7)}=1.80\right.$, $P=0.22$ and $\mathrm{F}_{(1,7)}=0.21, P=0.65$ respectively).

However, within the agroforests, ant species richness decreased on cacao trees when Anoplolepis gracilipes was present $\left(\mathrm{F}_{(1,44)}=8.05, P<0.05\right.$, Fig. 5). This effect was significant on the richness of

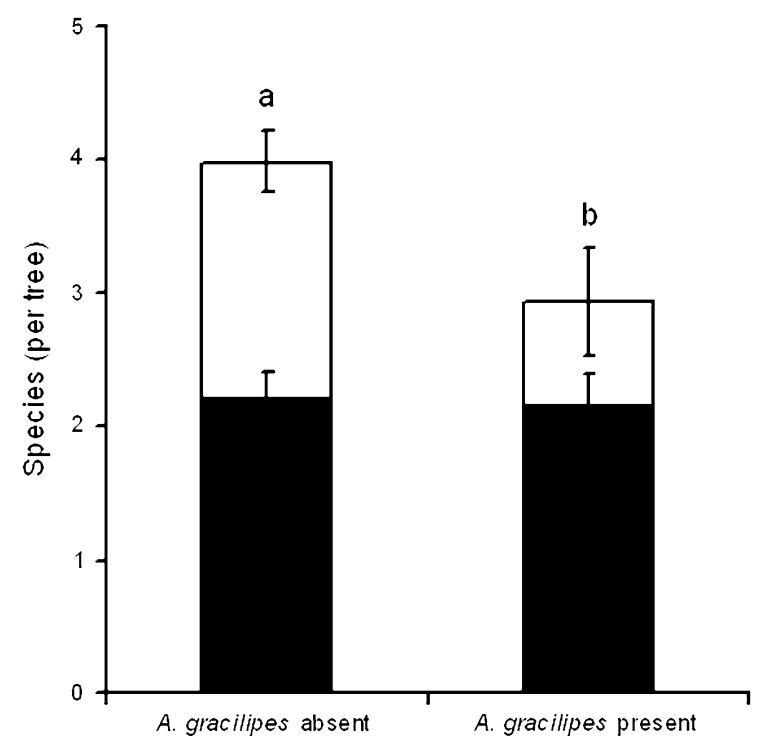

Fig. 5 The significant, negative effect of presence of Anoplolepis gracilipes on forest ant species (white) and the insignificant effect on non-forest species (black) on cacao trees in Central Sulawesi, Indonesia. We did not separate habitats or sites because these had no significant effects. Letters show significant differences according to Tukey's HSD post hoc test for comparisons with unequal sample sizes after the General Linear Model forest ants $\left(\mathrm{F}_{(1,44)}=11.62, P<0.005\right.$, Fig. 5), whereas richness of non-forest species remained unaffected $\left(\mathrm{F}_{(1,44)}=0.62, P=0.43\right.$, Fig. 5).

\section{Discussion}

Conservation biologists have identified tropical agroforests as one of the most species rich cultivated habitats (e.g., Perfecto et al. 1997; Schulze et al. 2004; Bos et al. 2007a). The ant richness of cacao agroforests in our study indeed remained comparable with that of lower canopy trees in nearby natural forest, despite the fact that ant assemblages were compared between a heterogeneous set of trees in the natural forest and cacao trees in the agroforests. However, the identity of the species changed considerably as almost half of the forest ant species were not found in agroforests and vice versa. High species turnover between tropical habitats is common, and can result from habitat heterogeneity at the landscape scale (e.g., Tylianakis et al. 2006; Bos et al. 2007b). In our comparison, most habitat differences at the landscape scale resulted from differences between natural forests and cacao-dominated agroforests, and the most common species that did not occur in both habitat types was the Yellow Crazy Ant Anoplolepis gracilipes (18\% of all ants collected from cacao trees).

The likelihood of successful species introductions can increase with increased propagule pressure ("introduction effort") (Lockwood et al. 2005). Propagule pressure can be measured as repeated accidental or purposeful introductions by humans and we tested whether the presence of A. gracilipes in agroforests was related to the distance to the village. The ant species occurred with highest densities in households and homegardens in the village, which is thus likely to be the source of further spread into the surrounding agroforests. However, there was no relation between distance to the village and the presence of A. gracilipes in the agroforests, which suggests additional or different factors to have facilitated the spread of $A$. gracilipes into the cacao agroforests. Alarmingly, the presence of $A$. gracilipes on cacao trees was concomitant with a significant decline in forest species, while non-forest species richness remained unaffected by changes in canopy cover, tree density, and the presence of A. gracilipes. This asymmetric response of forest species versus 
non-forest species emphasizes the threat that invasive ant species may pose to rare or endemic fauna (supporting Hill et al. 2003; O'Dowd et al. 2003; Sanders et al. 2003) and the asymmetric effects that habitat modification may have on the competitive dominance by different species (Tylianakis et al. 2007).

Anthropogenic disruption of ecosystems has been suggested to be a prerequisite to biological invasions (Elton 1958), and invasive species may be one of many proximate mechanisms through which habitat modification causes declines in species richness (Didham et al. 2007). The importance of habitat modification for ant dominance patterns has been shown empirically with increased dominance by ant species in altered habitats (Gibb and Hochuli 2003; Menke and Holway 2006). On the Seychelles, dominance by $A$. gracilipes threatens endemic island bird populations (Hill et al. 2003), and these islands have undergone intensive open phosphate mining prior to the current land cover by non-indigenous trees.

Ant communities can be sensitive to microclimatic changes that are related to shade removal in that changes in temperature asymmetrically affect ant species (Room 1971; Perfecto and Vandermeer 1996; Gibb and Hochuli 2003). Whereas our results did not reveal a relation between the presence of Anoplolepis gracilipes and the decrease in canopy cover, our results suggested a weak association with tree removal in that $A$. gracilipes was most likely to be found on cacao trees in agroforests with lowest tree density.

The thinning of tree stands may have affected the competitive dominance among ant species by decreasing the availability of canopy-related nesting sites and food resources (Philpott and Foster 2005). In sites with high tree density, tree-nesting and -foraging ant species may be favoured, whereas species that nest and forage in leaf-litter and soils may increase in competitive dominance in sites with reduced tree density (e.g., Armbrecht et al. 2004; Philpott and Armbrecht 2006). Anoplolepis gracilipes is a generalist with respect to nesting sites and food preferences and can develop supercolonies in warm and moist soils and litter layers (Abbott 2006) and is thus likely to profit from low tree densities at the cost of native tree-nesting and -foraging species. In our study, A. gracilipes was most common in the agroforest site with lowest tree density where it was particularly abundant in dense litter layers.

Similarly, because native ant assemblages may be better adapted to lower temperatures and higher tree densities that characterize natural forests, such communities may be more resilient against the establishment of non-native species such as Anoplolepis gracilipes. This may explain the striking absence of A. gracilipes in the natural forest sites, even though these sites were sometimes less than a kilometer away from sites where the species was found (Fig. 1). The minimum distance between study sites was within the foraging range of A. gracilipes (Abbott 2006), which implies that absence in a site was more likely to result from habitat characteristics such as nest-site availability and competitive dominance of native ants than from dispersal limitation.

Distances between natural forest sites and the village were significantly larger than between any of the agroforests and the village. Thus, the absence of A. gracilipes in the natural forest sites could also have been related to a delayed establishment of the ant in the natural forests. Such a "lag-time" between establishment and outbreak of A. gracilipes was observed on the Australian Christmas Island (O'Dowd et al. 2003) and on the Seychelles (Hill et al. 2003) where the ant occurred in low densities for decades before it reached pest densities with negative ecological impacts. However, our observations in forest margins in Central Sulawesi, Indonesia, are in support of observations in Sabah, Malaysia, where the ant has been abundant in forest margins and disturbed forest patches for years, while being absent or only occurring in low densities inside undisturbed rainforest sites (J. Drescher, pers. comm.). Further research should shed more light on the mechanisms of successful establishment of invasive species such as A. gracilipes in cultivated and natural habitats, and the consequences for predator-prey interactions (Perfecto and Armbrecht 2006).

\section{Conclusions}

Our results underscore the potentially important effects of invasive, exotic species on the forest fauna remaining after forest conversion to agroforest. More than half of the ant species we found on cacao trees were not found in adjacent forest sites and one of 
those species had well-known invasive attributes. This difference in species composition between natural forest and agroforests showed that species richness alone is not the best indicator of the conservation value of these systems as it may overlook important changes in community structure and species interactions. Our study suggests that a management-induced loss of trees may have paved the way for invasions by species that are generalists in their selection of nesting sites and food resources, with a disproportionately negative effect on forest species that should have highest priority in terms of biodiversity conservation.

Ecological dominance by an invasive species in cultivated habitats is rarely considered in the context of biodiversity conservation in tropical agroecosystems and we have shown that such dominance may be associated with losses of characteristic forest fauna, thereby threatening the potential of cultivated forests for biodiversity conservation. This link between ecologically dominant, invasive species and anthropogenic habitat modification is important to acknowledge in future studies to include the possible indirect effects of habitat destruction on native and invasive species. Thus, combating species losses after forest conversions may require a broader approach that incorporates habitat management schemes to control invasive species.

Acknowledgments We thank Tatyana Rand, Jochen Drescher, Phil Lester and an anonymous reviewer for helpful suggestions that improved previous versions of this manuscript. This work was funded by the German Research Foundation (DFG) grant SFB-552 ("STORMA" http://www.storma.de). We are very grateful to Akhmad Rizali and Rudy Kohout for their help in identifying ants. We thank Rhamadanil Pitopang (Herbarium Celebense, Indonesia) for identifying forest trees and Andre Twele (Geography Institute, Göttingen University, Germany) for supplying us with Fig. 1. Furthermore, we thank Damayanti Buchori (IPB Bogor, Indonesia), Pak Mann, Arifin, Daniel Stietenroth, Adam Malik, Wolfram Lorenz and Surya Tarigan for their help in the progress of this work.

\section{Appendices}

Appendix 1 Identifications of the 24 lower canopy trees from which ants were collected in four natural forest sites in Central Sulawesi, Indonesia. The site numbers correspond with those in Fig. 1

\begin{tabular}{|c|c|c|}
\hline Site number & Family & Species \\
\hline \multirow[t]{6}{*}{ A1 } & Apocynaceae & Tabernaemontana sp. \\
\hline & Euphorbiaceae & Mallotus moritzianus Muell. Dr. \\
\hline & Guttiferae & Garcinia sp. \\
\hline & Myristicaceae & Syzigium sp. \\
\hline & Oleaceae & Chionanthus nitens Koord. \& Valeton \\
\hline & Ulmaceae & Celtis rigescens (Miq.) Planch. \\
\hline \multirow[t]{6}{*}{ A2 } & Annonaceae & Goniothalamus philippinensis \\
\hline & Euphorbiaceae & Antidesma sp. \\
\hline & Fagaceae & Castanopsis accuminatissima (Blume) Rheder \\
\hline & Lauraceae & Endiandra macrophylla (Blume) Keerl. \\
\hline & Lauraceae & Litsea sp. 1 \\
\hline & Rubiaceae & Lasianthus sp. \\
\hline \multirow[t]{6}{*}{ A3 } & Gnetaceae & Gnetum gnemon L. \\
\hline & Indet. & Indet. \\
\hline & Lauraceae & Litsea sp. 2 \\
\hline & Meliaceae & Dysoxylum alliaceum (Blume) Blume \\
\hline & Myrtaceae & Syzigium accuminatissima \\
\hline & Rubiaceae & Psychotria sp. \\
\hline
\end{tabular}


Appendix 1 continued

\begin{tabular}{lll}
\hline Site number & Family & Species \\
\hline A4 & Moraceae & Ficus sp. 1 \\
& Moraceae & Ficus sp. 2 \\
& Celastraceae & Siphonodon celastrineus Grif. \\
& Oleaceae & Chionanthus nitens Koord. \& Valeton $(2 \times)$ \\
& Polygalaceae & Xanthophyllum sp. \\
\hline
\end{tabular}

Appendix 2 Number of ant individuals and species (in brackets) per genus, in forests (from 24 lower canopy trees) and agroforests (from 72 cacao trees in agroforests) in Central Sulawesi, Indonesia

\begin{tabular}{|c|c|c|c|c|}
\hline Subfamily & Genus & Forests & Agroforests & All species \\
\hline Aenictinae & Aenictus & $2(1)$ & $0(0)$ & $2(1)$ \\
\hline \multirow[t]{3}{*}{ Dolichoderinae } & Dolichoderus & $5(2)$ & $302(5)$ & $307(6)$ \\
\hline & Philidris & $1(1)$ & $0(0)$ & $1(1)$ \\
\hline & Technomyrmex & $8(1)$ & $1,268(2)$ & $1,276(2)$ \\
\hline Ectatomminae & Gnamptogenys & $93(1)$ & $59(1)$ & $152(1)$ \\
\hline \multirow[t]{6}{*}{ Formicinae } & Anoplolepis & $0(0)$ & $2,287(1)$ & $2,287(1)$ \\
\hline & Camponotus & $43(5)$ & $569(8)$ & $612(9)$ \\
\hline & Echinopla & $9(4)$ & $19(3)$ & $28(4)$ \\
\hline & Oecophylla & $4(1)$ & $69(1)$ & $73(1)$ \\
\hline & Paratrechina & $559(2)$ & $3,772(5)$ & $4,331(5)$ \\
\hline & Polyrhachis & $413(15)$ & $928(23)$ & $1,341(33)$ \\
\hline \multirow[t]{5}{*}{ Myrmicinae } & Cataulacus & $2(1)$ & $0(0)$ & $2(1)$ \\
\hline & Crematogaster & $27(2)$ & $2,381(4)$ & $2,408(4)$ \\
\hline & Pheidole & $105(1)$ & $0(0)$ & $105(1)$ \\
\hline & Pheidologeton & $0(0)$ & $4(1)$ & $4(1)$ \\
\hline & Tetramorium & $0(0)$ & $867(7)$ & $867(7)$ \\
\hline \multirow[t]{4}{*}{ Ponerinae } & Diacamma & $21(2)$ & $2(1)$ & $23(2)$ \\
\hline & Myopias & $0(0)$ & $1(1)$ & $1(1)$ \\
\hline & Odontomachus & $0(0)$ & $1(1)$ & $1(1)$ \\
\hline & Platythyrea & $0(0)$ & $2(1)$ & $2(1)$ \\
\hline Pseudomyrmecinae & Tetraponera & $2(1)$ & $10(1)$ & $12(1)$ \\
\hline Total & & $1,294(40)$ & $12,541(66)$ & $13,835(84)$ \\
\hline
\end{tabular}

\section{References}

Abbott KL (2006) Spatial dynamics of supercolonies of the invasive yellow crazy ant, Anoplolepis gracilipes, on Christmas Island, Indian Ocean. Divers Distrib 12:101-110 Achard F, Eva HD, Stibig H-J, Mayaux P, Callego J, Richards T, Malingreau J-P (2002) Determination of deforestation rates of the world's humid tropical forests. Science 297:999-1002

Armbrecht I, Perfecto I, Vandermeer J (2004) Enigmatic biodiversity correlations: ant diversity responds to diverse resources. Science 304:284-286
Basset Y (2001) Invertebrates in the canopy of tropical rain forest. How much do we really know? Plant Ecol 153:87-107

Bawa SS, Kress WJ, Nadkarni NM, Lele S (2004) Beyond paradise-Meeting the challenges in tropical biology in the 21st century. Biotropica 36:437-446

Bolton B (1994) Identification guide to the ant genera of the world. Harvard University Press, Cambridge, Massachusetts, USA

Bos MM, Steffan-Dewenter I, Tscharntke T (2007a) The contribution of shaded cacao agroforests to the conservation of lower canopy ants, and beetles in Indonesia. Biodivers Conserv 16:2429-2444 
Bos MM, Höhn P, Saleh S, Büche B, Buchori D, SteffanDewenter I, Tscharntke T (2007b) Insect diversity responses to forest conversion and agroforestry management. In: Tscharntke T, Leuschner C, Guhardja E, Zeller M (eds) The stability of tropical rainforest margins: linking ecological, economic and social constraints of land use and conservation. Springer, Berlin, Heidelberg, New York, pp 279-296

Colwell RK (2004) EstimateS: statistical estimation of species richness and shared species from samples. Version 7. User's Guide and application. http://purl.oclc.org/estimates

Didham RK, Tylianakis JM, Gemmell NJ, Rand TA, Ewers RE (2007) Interactive effects of habitat modification and species invasion on native species decline. Trends Ecol Evol 22(9):489-496

Elton CS (1958) The ecology of invasions. Methuen Wiley, London, New York

Gibb H, Hochuli DF (2003) Colonisation by a dominant ant facilitated by anthropogenic disturbance: effects on ant assemblage composition, biomass and resource use. Oikos 103:469-478

Gradstein SR, Kessler M, Pitopang R (2007) Tree species diversity relative to human land uses in tropical rain forest margins in Central Sulawesi. In: Tscharntke T, Leuschner C, Guhardja E, Zeller M (eds) The stability of tropical rainforest margins: linking ecological, economic and social constraints of land use and conservation. Springer, Berlin, Heidelberg, New York, pp 321-334

Hill M, Holm K, Vel T, Shah NJ, Matyot P (2003) Impact of the introduced crazy ant Anoplolepis gracilipes on Bird Island, Seychelles. Biodivers Conserv 12:1969-1984

Hoekstra JM, Boucher TM, Ricketts TH, Roberts C (2005) Confronting a biome crisis: global disparities of habitat loss and protection. Ecol Lett 8:23-29

Holway DA, Lach L, Suarez AV, Tsutsui ND, Case TJ (2002a) The causes and consequences of ant invasion. Annu Rev Ecol Syst 33:181-233

Holway DA, Suarez AV, Case TJ (2002b) Role of abiotic factors in governing susceptibility to invasion: a test with argentine ants. Ecology 83:1610-1619

Lockwood JL, Cassey P, Blackburn T (2005) The role of propagule pressure in explaining species invasions. Trends Ecol Evol 20:223-228

Majer JD, Delabie JHC, Smith MRB (1994) Arboreal ant community patterns in Brazilian cocoa farms. Biotropica 26:73-83

McNeely JA (2004) Nature vs. nurture: managing relationships between forests, agroforestry and wild biodiversity. Agroforest Syst 61:155-165

Menke SB, Holway DA (2006) Abiotic factors control invasion by Argentine ants at the community scale. J Anim Ecol 75:368-376

Millennium Ecosystem Assessment (2005) Ecosystems and human well-being: synthesis. Island Press, Washington, DC

Myers N, Mittelmeier RA, Mittelmeier CG, da Fonseca GAB, Kent J (2000) Biodiversity hotspots for conservation priorities. Nature 493:853-858

O'Dowd DJ, Green PT, Lake PS (2003) Invasional 'meltdown' on an oceanic island. Ecol Lett 6:812-817

Perfecto I, Vandermeer J (1996) Microclimatic changes and the indirect loss of ant diversity in a tropical agroecosystem. Oecologia 108:577-582
Perfecto I, Vandermeer J, Hanson P, Cartín V (1997) Arthropod biodiversity loss and the transformation of a tropical agro-ecosystem. Biodivers Conserv 6:935-945

Philpott SM, Foster PF (2005) Nest-site limitation in coffee agroecosystems: artificial nests maintain diversity of arboreal ants. Ecol Appl 15:1478-1485

Philpott SM, Armbrecht I (2006) Biodiversity in tropical agroforests and the ecological role of ants and ant diversity in predatory function. Ecol Entomol 31:369-377

Potter L (2001) Agricultural Intensification in Indonesia: outside pressures and indigenous strategies. Asia Pac Viewp 42:305-324

Rice RA, Greenberg R (2000) Cacao cultivation and the conservation of biological diversity. Ambio 29:167-172

Room PM (1971) The relative distribution of ant species in Ghana's cocoa farms. J Anim Ecol 40:735-751

Sanders NJ, Gotelli NJ, Heller NE, Gordon DM (2003) Community disassembly by an invasive species. Proc Natl Acad Sci USA 100:2474-2477

Schroth G, da Fonseca GAB, Harvey CA, Gascon C, Vasconcelos HL, Izac A-MN (2004) Agroforestry and biodiversity conservation in tropical landscapes. Island Press, Washington, DC

Schulze CH, Waltert M, Kessler PJA, Pitopang R, Shahabuddin, Veddeler D, Muhlenberg M, Gradstein SR, Leuschner C, Steffan-Dewenter I, Tscharntke T (2004) Biodiversity indicator groups of tropical land-use systems: comparing plants, birds and insects. Ecol Appl 14:1321-1333

StatSoft Inc. (1984-2004). STATISTICA for Windows [Software-System for Data-analyses] Version 7.0. Tulsa, USA

Steffan-Dewenter I, Kessler M, Barkmann J, Bos MM, Buchori D, Erasmi S, Faust H, Gerold G, Glenk K, Gradstein SR, Guhardja E, Harteveld M, Hertel D, Höhn P, Kappas M, Köhler S, Leuschner C, Maertens M, Marggraf R, MiggeKleian S, Mogea J, Pitopang R, Schaefer M, Schwarze S, Sporn SG, Steingrebe A, Tjitrosoedirdjo SS, Tjitrosoemito S, Twele A, Weber R, Woltmann L, Zeller M, Tscharntke $\mathrm{T}$ (2007) Tradeoffs between income, biodiversity, and ecosystem functioning during tropical rainforest conversion and agroforestry intensification. PNAS 104: 4973-4978

Tscharntke T, Klein A-M, Kreuss A, Steffan-Dewenter I, Thies C (2005) Landscape perspectives on agricultural intensification and biodiversity-ecosystem service management. Ecol Lett 8:857-874

Tylianakis JM, Klein AM, Lozada T, Tscharntke T (2006) Spatial scale of observation affects alpha, beta and gamma diversity of cavity-nesting bees and wasps across a tropical land-use gradient. J Biogeogr 33:1295-1304

Tylianakis JM, Tscharntke T, Lewis OT (2007) Habitat modification alters the structure of tropical host-parasitoid food webs. Nature 445:202-205

Vitousek PM, D'Antonio CM, Loope LL, Westbrooks R (1996) Biological invasions as global environmental change. Am Sci 84:468-478

Wetterer JK (2005) Worldwide distribution and potential spread of the long-legged ant, Anoplolepis gracilipes (Hymenoptera: Formicidae). Sociobiology 45:77-97 